\title{
The Initial Managerial Competence of Teachers Nominated as School Principal Candidates and the Response of Educational Authorities to the Policy of Principal Preparation Program
}

\author{
Ratna Juwita ${ }^{1}$, Ady Saefudin ${ }^{1}$ \\ ${ }^{1}$ Lembaga Pengembangan dan Pemberdayaan Kepala Sekolah, Kp. Dadapan, RT 06 RW 07, \\ Jatikuwung, Gondangrejo, Karanganyar
}

\begin{abstract}
Peraturan Menteri Pendidikan Nasional/Permendiknas (Regulation of the Minister of National Education) Number 13 Year 2007 states that managerial competence is one out of five mandatory competencies that must be possessed by school principals. Teachers are not required to posses this competence, but as they are nominated as school principals, they must acquire this managerial competence. Further, Permendiknas Number 28 Year 2010 defines that school principals are to be prepared through a series of administrative and academic selection, and yet educational training which is called the Principal Preparation Program (PPP). PPP is aimed at, one of which, preparing school principal candidates to be able to play their roles as school managers. Previous studies show that among the five dimensions of school principals' competence, managerial dimension plays a vital role in determining the success of school principals in managing their schools. Based on the above two-requirements stated by the regulations concerning school principals, and the initial observation concerning the extent to which education authorities responding to the policies, this study aims to describe the initial ability of teachers who are nominated as school principals and the extent to which education authorities in districts/cities/provinces responding to the policy of PPP. Initial capability data were collected through the AKPK (the Professional Development Need Analysis/PDNA) instrument which was distributed to 919 principal candidates in 10 provinces and 33 districts/cities. The result of data analysis shows that the average initial ability of principal candidates' managerial competence is in moderate category (2.8). The two lowest indicators of the managerial competence of principal candidates are the mastery of ICT (Information and Communication Technology) and the implementation of monitoring and evaluation. However, data show that a total of 42.6\% of the Provincial/District/City Education Authorities has not responded well to PPP policy as one of alternative ways to improve the managerial competence of principal candidates. Both findings imply that every teacher nominated as school principal should be provided with knowledge, skill and attitude constructing school principals' managerial competence, especially in the utilization of ICT and the implementation of monitoring and evaluation. Provincial/District/City Education Authorities must be further informed about the PPP as the program of the Ministry of Eduation in promoting school principals.
\end{abstract}

Keywords: Permendiknas number 13 year 2007; managerial competence; principal candidate; AKPK/PDNA instrument; Principal Preparation Program (PPP) 


\section{INTRODUCTION}

Peraturan Menteri Pendidikan Nasional/Permendiknas (Regulation of the Minister of National Education) Number 13 Year 2007, regarding The Standard of School Principal, explains that there are five dimensions of competence that must be possessed by school principal. The five dimensions of school principal competence are personality, managerial, entrepreneurial, supervision and social competence. Managerial dimension is one of the highest of importance in performing duties of school principal. Peraturan Pemerintah/PP (Government Regulation) Number 19 Year 2017, article 54, paragraph 1, states that the workload of school principal lies fully on managerial duties, entrepreneurship development and supervision to teachers and educational personnel. This regulation emphasizes the importance of school principal's managerial competence. School principal is now mostly manager, not teacher as it is required before in previous years.

The importance of school principal managerial competence was confirmed by a research conducted by Sulfianti in 2013. An important finding in this study suggests that principal managerial competence contributes significantly to teacher working motivation. The ability of school principals in managing all the elements within school affects teachers' working motivation (Sulfiati, 2013) [1]. The higher the ability of the principal in managing the school, the higher the motivation of teachers in daily work.

Sulistyorini, 2001, proved that there is a relationship between the principal's managerial skills and the organizational climate on teacher performance. The performance of teachers relates positively to principal's managerial skills (Sulistyorini, 2001) [2]. Zion Holten also supports the notion that the principal's managerial competence is essential. His study proved that the principal's managerial skills have a significant relationship to teacher teaching performance (Holten, 2015: 13-14) [3]. The principal must actively influence the school through vision, mission, organizational structure, educators and education and clear working methods. Principals should also build good cooperation with school stakeholders in order to invite them to achieve higher goals. It reflects much of what is known as effective schools, and has sometimes been labeled as pre-conditions for school improvement (Gurr, 2015) [4].

The key to leading leaders is to develop managerial competence. Sybouts, in his book The Training and Development of School Principals, states that:

"Principals in effective schools work to shape school culture. Subcultures exist in school systems. Therefore, principals must recognize these differences and work together to articulate shared values and a common way to bond subcultures to the school as a whole. As leaders, principals must understand the nature of groups to be led. Thus, rather than being a leader of followers, the principal's role has changed to be a leader of leaders (Sybouts, 1994) [5] ".

Good principal shapes school culture. School culture is built from best practises or best systems done by teachers, students, and administration staffs. The principal should understand how to influence, to move, to develop and to empower teachers, students, and administration staffs, so they can move in one direction.

The importance of the principal's managerial competence requires the preparation of a principal candidate. Teachers who will be sworn in as principal should be provided with sufficient knowledge, skills and attitude. Permendiknas Number 28 Year 2010 confirms that the Principal Preparation Program (PPP), which one of the important 
stage is the Principal Candidate Educational Training (Diklat Calon Kepala Sekolah). This educational training aims at equipping principal candidates with knowledge, skills and attitude related to the five dimensions of principal competence. Instructional training patterns is In-On-In (In-Service Learning 1, On-the-Job Learning, In-Service Learning 2), and it has been acknowledged as the most effective training pattern to equip principal candidates in theory and practice (Juwita, 2015) [6].

The Education Sector Analytical and Capacity Development Partnership (ACDP) has reviewed the quality and subject matter of the Principal Candidates Educational Training. Most respondents claimed that they viewed the quality of PPP educational training as excellent, especially when compared to other training. The reasons are that: 1) this training provides an understanding and guidance on how to become a candidate for school principal, 2) this training can improve the quality and competence of school principal, 3) this training makes school principal be able to manage school administration properly. Moreover, the training materials provided at PPP are deemed 'relevant' or 'highly relevant', according to PPP participants from four levels of school. In fact, between half to two thirds of respondents from Vocational High School (SMK) consider PPP material is 'highly relevant' (ACDP, 2016) [7].

Permendiknas Number 13 Year 2007 and the results of the studies above prove that principals' managerial competence is an important competence, and it influences school performance. Principal candidates must follow the standardized educational training as arranged in Permendiknas Number 28 Year 2010 to get provision of theories and practices about the five dimensions of school principal competence. Moreover, data on the managerial competence of school principal is less encouraging. Rosalina, 2015, found that the principal managerial competence in the Padang Timur scored only $78.6 \%$ (Rosalina, 2015) [8]. Herewith, school principal needs training and guidance by school supervisors. The ACDP study, in 2013, found out that the managerial competence of principals is also low. The lowest scoring indicator of the principal is the ability to manage ICTs for school organization and management. Issues related to ICTs also appear in other dimensions as a field that needs to be improved and developed for principals (ACDP, 2013) [9].

The difference between the highly importance of managerial competence for school principals and the fact that school principals possess low level of managerial competence is the subject of this study. The objects of previous studies are principals who have held the position. In contrast, the objects of this sudy are teachers as school principal candidates. Those who have not been appointed as principals yet. This study will answer the two questions below:

1. How is the initial ability of teachers nominated as school principal in managerial competence?

2. How do District/City/Provincial Education Authorities respond to the PPP policy as a way of improving the managerial competence of teachers nominated as school principals?

\section{METHODS}

This study is a descriptive study. According to Erna and Mukhtar Widodo (2000) [10], descriptive method is not intended to test a particular hypothesis, but rather to describe what is the existence of a symptom, variable, or state. However, it does not 
mean that all descriptive studies do not use hypotheses. The use of hypotheses in descriptive research is not intended to be tested, but at how to try to find something meaningful as an alternative in overcoming research problems through scientific procedures. Another opinion suggests that descriptive method is a method of researching the status of a human group, an object, a set of conditions, a system of thought, or a class of events in the present (Moh Nazir 2003) [11]. From the above descriptions, it can be stated that this descriptive study is aimed at describing the initial ability of teachers nominated as school principal in the dimension of managerial competence, and developing alternative solution to the school principals' low level of managerial competence through scientific procedures.

Instruments used in this study are questionnaires and document studies. Researchers use a questionnaire containing a list of questions asked to respondents to respond (Purwanto, 2007) [12]. The questionnaire method is used in capturing initial capability data of principal candidates in the dimension of managerial competence. Questionnaires were distributed throughout the district/city. The sample of this research is 919 principal candidates from 10 Provinces, 33 district/city who joined the PPP in 2016.

TABLE I. LIST OF RESPONDENTS/ PPP PARTICIPANTS IN 2016

\begin{tabular}{|c|c|c|}
\hline Provinces & District/City & Respondents \\
\hline \multirow{4}{*}{ Aceh } & Kabupaten Aceh Tamiang & 30 \\
\hline & Kabupaten Bireun & 30 \\
\hline & Kabupaten Gayo Lues & 30 \\
\hline & Kabupaten Lhokseumawe & 24 \\
\hline Bali & Kabupaten Badung & 30 \\
\hline \multirow{3}{*}{ Bengkulu } & Kabupaten Bengkulu Selatan & 30 \\
\hline & Kabupaten Bengkulu Tengah & 26 \\
\hline & Kabupaten Bengkulu Kota & 19 \\
\hline \multirow{3}{*}{ DIY } & Kabupaten Bantul & 26 \\
\hline & Kabupaten Kulon Progo & 30 \\
\hline & Kabupaten Sleman & 30 \\
\hline \multirow{4}{*}{ Jawa Barat } & Kabupaten Indramayu & 30 \\
\hline & Kabupaten Majalengka & 30 \\
\hline & Kabupaten Purwakarta & 30 \\
\hline & Kabupaten Kota Bandung & 30 \\
\hline \multirow{4}{*}{ Jawa Tengah } & Kabupaten Tegal & 30 \\
\hline & Kota Salatiga & 30 \\
\hline & Kota Semarang & 30 \\
\hline & Kota Surakarta & 16 \\
\hline \multirow{4}{*}{ Jawa Timur } & Kabupaten Magetan & 30 \\
\hline & Kabupaten Malang & 30 \\
\hline & Kabupaten Pacitan & 30 \\
\hline & Kabupaten Ponorogo & 30 \\
\hline \multirow{4}{*}{ Kalimantan Barat } & Kabupaten Kayong Utara & 17 \\
\hline & Kabupaten Ketapang & 30 \\
\hline & Kabupaten Melawi & 17 \\
\hline & Kabupaten Mempawah & 30 \\
\hline \multirow{2}{*}{ Maluku Utara } & Kabupaten Buru & 24 \\
\hline & Kabupaten Kep.Sula & 30 \\
\hline
\end{tabular}




\begin{tabular}{|llc|}
\hline Provinces & \multicolumn{1}{c|}{ District/City } & Respondents \\
\hline & Kabupaten Tidore Kepulauan & 30 \\
\hline \multirow{3}{*}{ Riau } & Kabupaten Indragiri Hulu & 30 \\
\cline { 2 - 3 } & Kabupaten Kampar & 30 \\
\cline { 2 - 3 } & Kabupaten Kep. Meranti & 30 \\
\hline & & 919 \\
\hline
\end{tabular}

The questionnaire is a valid questionnaire from LPPKS (Lembaga Pengembangan dan Pemberdayaan Kepala Sekolah/ the Institution of Developing and Empowering School Principals), which is called the AKPK (Analisis Kebutuhan Pengembangan Keprofesian/PDNA (Professional Development Need Analysis)) instrument. The questionnaire is derived from 16 indicators of managerial competence dimension written in Permendiknas Number 13 Year 2007, which is summarized into 14 indicators for the purposes of research.

Firstly, the researcher held a meeting with enumerators. This meeting aims to ensure that the enumerators understand the questionnaire substance and inform the does and the dont's. Next, the enumerators distributed the questionnaires, explained the purpose and collected the data. Respondent filled out a questionnaire by using a fourpoint Likert scale:

1- poor, 2- fair, 3- good, 4- very good. Finally, the enumerator input the data and the reseacher analyzed the data (see Figure 1).

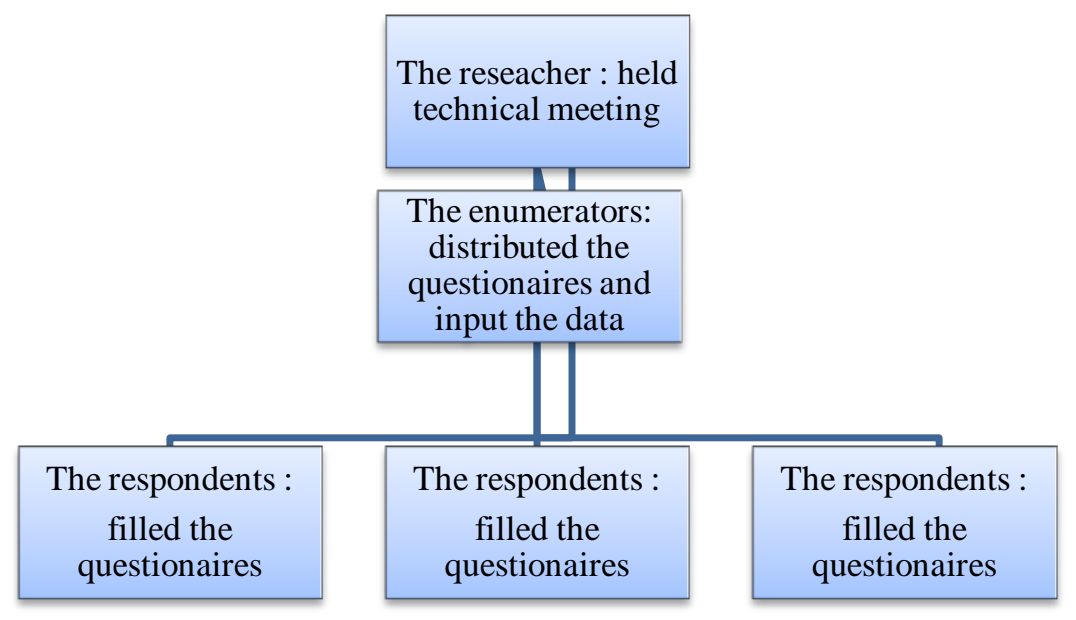

Figure 1. Chart of data collection

The researchers analyzed data from the enumerators and prepared the report. There were three elements involved in this data collection, i.e. researchers, enumerators and respondents.

The second method was interview. The interview was conducted to the Head and staff of the Competence Improvement Section (Seksi Peningkatan Kompetensi) of LPPKS to explore information related to the extent of which the District/City/Provincial Education Authorities responding to the implementation of the PPP. 
The third method used was documentation study. According to Sugiyono (2013: 240) [13], a document is a record of events that have passed. Documents may be writings, drawings, or monumental works of a person. Writing documents such as diaries, life histories, stories, biographies, regulations, policies. The researcher collected data from the official documents of LPPKS (Petunjuk Pelaksanaan and Petunjuk Teknis of PPP/the Implementation Instruction and the Technical Instruction of PPP) and the official website at nuks.lppks.org. Petunjuk Pelaksanaan and Petunjuk Teknis of PPP is a document containing policies on preparing school principal candidates, program structure and certification. While the website Portal Update Data NUKS contains the data of school principals in Indonesia who have attended the PPP and who have held the certificate of principal.

TABLE II. RESEARCH QUESTIONS, METHODS AND RESPONDENTS

\begin{tabular}{|l|l|l|}
\hline \multicolumn{1}{|c|}{ Reasearch questions } & \multicolumn{1}{c|}{$\begin{array}{c}\text { Reaserch } \\
\text { Method }\end{array}$} & Respondents \\
\hline $\begin{array}{l}\text { How is the initial ability of teachers } \\
\text { nominated as school principal in managerial } \\
\text { competence? }\end{array}$ & Questionire & $\begin{array}{l}\text { School Principal } \\
\text { Candidates }\end{array}$ \\
\hline $\begin{array}{l}\text { How do District/City/Provincial Education } \\
\text { Authorities respond to the PPP policy as a } \\
\text { way of improving the managerial } \\
\text { competence of teachers nominated as } \\
\text { school principals? }\end{array}$ & $\begin{array}{l}\text { Interview and } \\
\text { documentation }\end{array}$ & $\begin{array}{l}\text { The head and } \\
\text { staffs of Seksi } \\
\text { Peningkatan } \\
\text { Kompetensi of } \\
\text { LPPKS }\end{array}$ \\
\hline
\end{tabular}

\section{RESULTS AND DISCUSSIONS}

\section{The initial ability of teachers nominated as school principal in managerial competence}

The data were collected through AKPK instrument. The questionnaire is derived from 16 indicators of managerial competence dimension written in Permendiknas Number 13 of 2007, which is summarized into 14 indicators for the purposes of research. The principal candidates was required to assess their managerial competence for each indicator by using a four-point likert scale:

1 - poor, 2 - fair, 3 - good, 4 - very good.

Based on the data analysis, the mean of initial ability of teachers nominated as school principal in managerial competence was 2,8 (between fair and good). The result supports the previous assumption that the lack of managerial competence of school principal is at some part due to the low competence of the school principal candidates. The findings are as follows;

1. The lowest indicators are utilization of ICT and knowledge acquisition of monitoring and evaluation ( score 2,6)

2. The low indicators are school planning, knowledge acquisition of Educational Staff and Administration ( score 2,7)

3. The highest indicators is student admission planning (score 3.2) and analyzing syllabus and lesson plan (score 3.1) 
TABLE III. THE SUMMARY OF INITIAL ABILITY OF TEACHERS NOMINATED AS SCHOOL PRINCIPAL IN MANAGERIAL COMPETENCE FOR EACH INDICATORS

\begin{tabular}{|lr|}
\hline Indicators & Score \\
\hline School plan & 2,7 \\
\hline Competences and qualifications of teacher & 3 \\
\hline Competences and qualifications of education personnel & 2,7 \\
\hline SPM \& SNP (national standarts) & 2,8 \\
\hline Infrastuctures & 2,8 \\
\hline Student admission planning & 3,2 \\
\hline Student coaching & 3 \\
\hline Student management & 3 \\
\hline Curriculum development (KTSP Dokumen 1) & 2,9 \\
\hline Syllabus and lesson plan & 3,1 \\
\hline Finance & 2,8 \\
\hline Administration & 2,7 \\
\hline ICT & 2,6 \\
\hline Monitoring and Evaluation (Monev) & 2,6 \\
\hline Mean & 2,8 \\
\hline
\end{tabular}

The finding is in line with ACDP's findings in 2013, that the lowest indicator is the ability to manage ICTs for school organization and management. Issues related to ICTs also appeared in other dimensions as one area that needs to be improved.

TABLE IV. SUMMARY OF INITIAL ABILITY OF TEACHERS NOMINATED AS SCHOOL PRINCIPAL IN MANAGERIAL COMPETENCE FOR EACH PROVINCE

\begin{tabular}{|lcccccccccc|}
\hline \multicolumn{1}{|c}{$\begin{array}{l}\text { Indicators/ } \\
\text { Province }\end{array}$} & Aceh & Bali & Bengkulu & DIY & Jabar & Jateng & Jatim & Kalbar & Malut & Riau \\
\hline School plan & 2,8 & 2,9 & 2,5 & 2,7 & 2,8 & 2,7 & 2,7 & 2,6 & 2,5 & 2,8 \\
\hline $\begin{array}{l}\text { Competences } \\
\text { and } \\
\text { qualifications } \\
\text { of teacher }\end{array}$ & 2,9 & 2,8 & 2,8 & 2,8 & 3,1 & 3,2 & 2,9 & 2,8 & 3 & 3 \\
\hline $\begin{array}{l}\text { Competences } \\
\text { and } \\
\text { qualifications } \\
\text { of education } \\
\text { personnel }\end{array}$ & 2,8 & 2,7 & 2,6 & 2,5 & 2,9 & 2,6 & 2,7 & 2,7 & 2,7 & 2,8 \\
\hline $\begin{array}{l}\text { SPM \& SNP } \\
\text { (national } \\
\text { standarts) }\end{array}$ & 2,7 & 2,9 & 2,5 & 2,7 & 3 & 2,8 & 2,7 & 2,8 & 2,6 & 2,9 \\
\hline $\begin{array}{l}\text { Infrastuctures } \\
\text { naturnt }\end{array}$ & 2,8 & 2,8 & 2,5 & 2,7 & 3,1 & 2,8 & 2,7 & 2,7 & 2,6 & 2,9 \\
\hline $\begin{array}{l}\text { Student } \\
\text { admission } \\
\text { planning }\end{array}$ & 3,1 & 3,3 & 3 & 3,1 & 3,3 & 3,3 & 3,1 & 3,1 & 3 & 3,3 \\
\hline $\begin{array}{l}\text { Student } \\
\text { coaching }\end{array}$ & 3 & 3,1 & 2,9 & 2,9 & 3,2 & 3,1 & 3 & 3 & 3 & 3 \\
\hline
\end{tabular}




\begin{tabular}{|lcccccccccc|}
\hline \multicolumn{1}{|c}{$\begin{array}{l}\text { Indicators/ } \\
\text { Province }\end{array}$} & Aceh & Bali & Bengkulu & DIY & Jabar & Jateng & Jatim & Kalbar & Malut & Riau \\
\hline $\begin{array}{l}\text { Student } \\
\text { management }\end{array}$ & 2,9 & 3 & 2,9 & 3 & 3,1 & 3 & 2,9 & 2,7 & 2,8 & 3 \\
\hline $\begin{array}{l}\text { Curriculum } \\
\text { development } \\
\text { (KTSP } \\
\text { Dokumen 1) }\end{array}$ & 3,1 & 3,1 & 2,9 & 2,9 & 3,2 & 2,9 & 2,7 & 2,8 & 2,8 & 3,1 \\
\hline $\begin{array}{l}\text { Syllabus and } \\
\text { lesson plan }\end{array}$ & 3 & 3,3 & 2,9 & 3 & 3,2 & 3,1 & 3 & 3 & 3,1 & 3,2 \\
\hline $\begin{array}{l}\text { Finance } \\
\text { ICT }\end{array}$ & 2,9 & 2,9 & 2,5 & 2,9 & 3,1 & 2,9 & 2,8 & 2,9 & 2,4 & 2,8 \\
\hline $\begin{array}{l}\text { Administratio } \\
\mathrm{n}\end{array}$ & 2,9 & 2,6 & 2,3 & 2,6 & 3 & 2,7 & 2,6 & 2,7 & 2,5 & 2,8 \\
\hline $\begin{array}{l}\text { Monitoring } \\
\text { and } \\
\text { Evaluation } \\
\text { (Monev) }\end{array}$ & 2,7 & 2,4 & 2,2 & 2,6 & 2,9 & 2,8 & 2,6 & 2,6 & 2,5 & 2,7 \\
\hline
\end{tabular}

The lowest indicators that should be considered by Aceh are SPM \& SNP (the National Standard of Public Service \& the National Standard of Education), ICT and monitoring and evaluation. On the other hand, the highest indicators are the student coaching and the analysis of syllabus and lesson plan. The lowest indicator of Bali Province is the utilitation of ICT. That is suprising, because Bali is an urban area where access to information and communication technology is highly sufficient. However, respondents from Bali argued that utilization of ICT in learning was highly needed. Student management and the preparation of syllabus and lesson plan are in good category. The lowest indicators in Bengkulu are monitoring and evaluation and school administration. While the lowest indicators in Yogyakarta is the management of educational personnel, such as laboratory staff, librarian, and administrative personnel. Utilization of ICT should be considered by West Java, Central Java and East Java. Although the quantitative achievement in ICT indicators in Java is higher than other provinces, but compared to other indicators, ICTs are the lowest. The demand for utilization of ICT in Java is very high. Consequently, all principal candidates from Java should master ICT well. The lowest indocators in West Kalimantan are administration, monitoring and evaluation, and ICT. An interesting phenomenon found in North Maluku, the lowest indicator is financial management. Principal candidates from North Maluku requires intensive debriefing in identifying school financial resources, financial management and financial report. The last province is Riau, which requires debriefing on ICT and monitoring and evaluation indicators.

According to the data, school principal candidates need to improve their knowledge and skill in managerial competence before being a school principal. The indicator of managerial competence that should be paid high attention is the utilization of ICT and monitoring and evaluation. Both indicators are found in the lowest level, in the indicators table (Table 3) or in provinces table (Table 4). 
R.J Botha, 2011, argued that the principal managerial competence is very important in determining teacher professionalism. District/City/Provincial Education Authorities should hold education and training in managerial competence, especially in the utilization of ICT and monitoring and evaluation, to support teachers professionalism (Botha, 2011) [14].

\section{The response of the District/City/Provincial Education Authorities to PPP policy as a way of improving the managerial competence of teachers nominated as school principal}

Based on Permendiknas Number 28 Year 2010, teachers, nominated as school principals, must follow the education and training in order to master the principal's competence. Managerial competence is one of the competencies required to be mastered in the education and training. Peterson and Kelley (2002) in Linda Darling (2010) [15] said that principal candidates should be equipped with an appropriate preparation program that has a clear, comprehensive vision and supports sustainable career development. Peterson and Kelley stressed that:

"...features that are similar to exemplary features of leadership preparation programs: having a clear vision; coherence; and a thoughtful sequencing of career development knowledge, skills and abilities. They also conclude that stronger programs offer a long-term set of experiences; combine workshops or institutes with on-site training, practice, and coaching; are closely linked to participants' work; and foster a sense of membership (p.19-20).

Sharp (2013) [16] argued that "although instructional leadership remains the central expectation of the principalship, the scope of the school-site management role has grown substantially over the years" (p.9-11). Peraturan Pemerintah (Government Regulation) number 19 year 2017 explains the same thing, the main role of principal is as school manager. Consequently, all school principal candidates should master managerial competence before being a real school principal.

Data from nuks.lppks.org mention that 356 out of 514 districts/cities in Indonesia, or about $69 \%$ have prepared candidates for their principals through the PPP. It means that about 158 districts/cities do not equip their principal candidates with the managerial competence through PPP. Each year, LPPKS, on behalf of the Ministry of Education and Culture gives an opportunity for the District/City/Provincial Education Authorities to hold the PPP on government budget. The result of documentation study in LPPKS shows that, in 2017, 86 offering letters had been sent to District/City/Provincial Education Authorities. In details, 29 letters were sent to the Provincial Education Department, and 57 letters were sent to the District/City Education Office.

LPPKS offers PPP to District/City/Provincial Offices because: (1) the District/City/Province who has not attended PPP yet, (2) the District/City/ Province has no local budget to conduct PPP, and (3) the District/City/ Province sends letters to LPPKS to be chosen as the PPP targets. As a result of interviews with the Head of Seksi Peningkatan Kompetensi of LPPKS, it is only 7 Provincial Education Offices and 1 Provincial Ministry of Religious Affairs, out of 29 Provincial Education Offices offered, that are ready to attend the PPP. The other 21 stated that they were not ready, because they were in transition period from the District/City Service to the Province. They do not have any accurate database on the projection of school principal in 
SMA/SMK from each district city. That is the reason why they could not accept the offer.

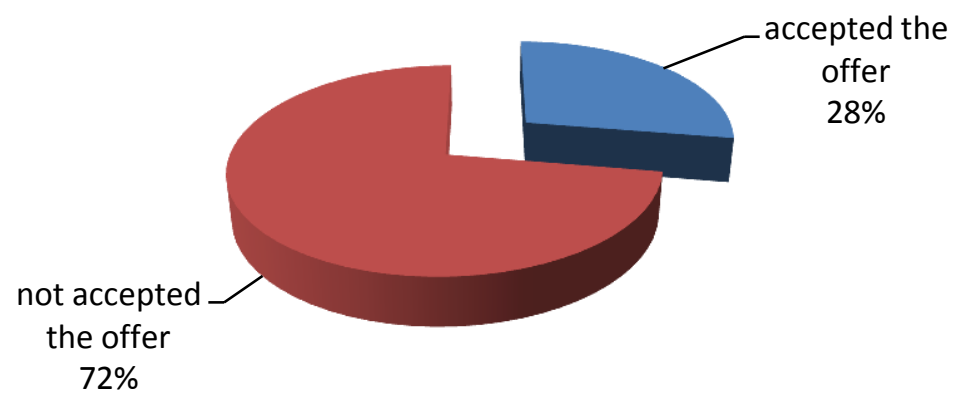

Figure 2. PPP offers for provincial education authorities in 2017

Out of 57 District/City Education Offices, 50 districs stated that they are ready to attend the PPP and 7 Districts stated are not ready. The reasons for the unpreparedness of the 7 districts/cities are (1) 2 districts/cities have waiting list of principal from the previous year, (2) 2 districts/cities are already in cooperation with other institutions, (3) 2 districts/cities are not responding at all, and (4) 1 district/city experiencing flood disaster, so they lost of information and communication.

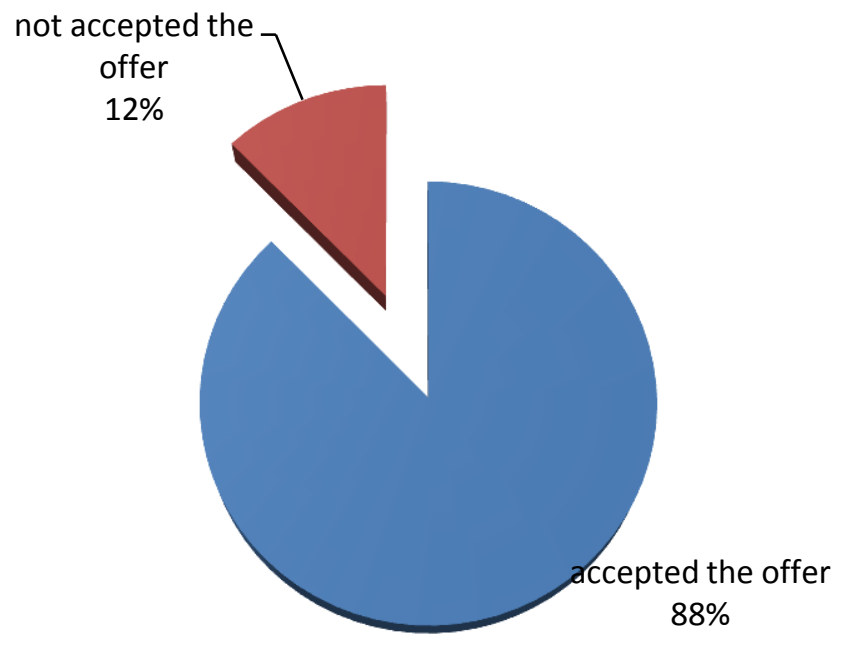

Figure 3. PPP offers for district/city education authorities in 2017 


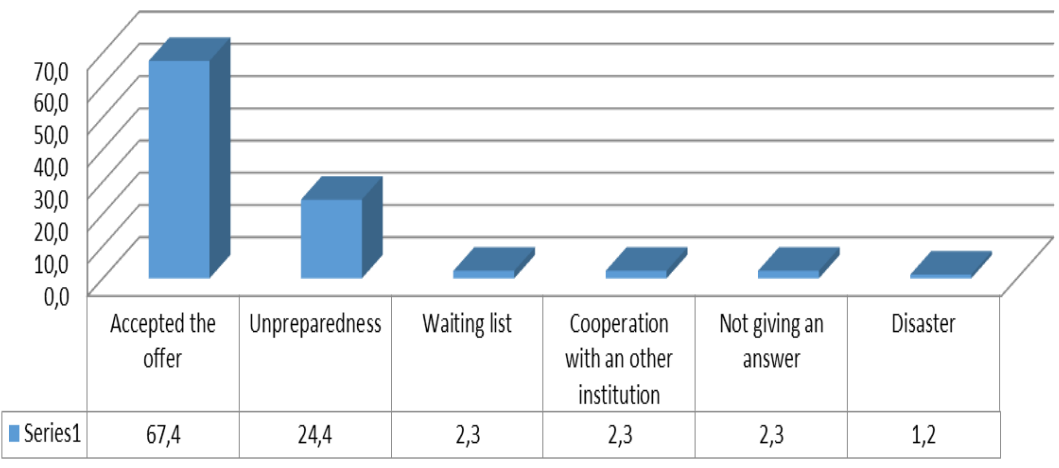

Figure 4. Chart of district/city/provincial education authorities responses on PPP

Based on tha data, about $67.4 \%$ of the Education Authorities accept the offer and $32.6 \%$ reject the offer because of unpreparedness, waiting list, cooperation with other institutions, not giving answers and disasters.

It is an ironic fact when, at one hand, Indonesian Government has provided a program and the budget, but on the other hand, the Education Authorities do not respond well to the offers of PPP. Though this program is very helpful to prepare teachers who will be inaugurated as principal. Lortie (2009) [17] said in his research that:

... "for most of our principals, the transition from teaching to principal was abrupt. Although around half had some prior administrative experience, only $13 \%$ felt that it constituted signifi cant preparation for the new position; of those, only two did not talk about things they had to learn. In their first day on the job, the rest of these men and women began work without a clear idea of what they are were expected to do; they knew practically nothing, for example, about the many routines they were expected to carry out; they were forced to rely heavily on the building secretary, if they were lucky enough to have an experienced one, during those initial months... (p.31-32).

The Education Authorities hold the highest responsibility in preparing teachers to be nominated as school principals. The Education Authorities can work hand in hand with LPPKS as the government institution bearing the authority of conducting PPP and issueing Certificate of School Principal.

\section{CONCLUSION}

The low level of managerial competence of the principal is caused by the low level of managerial competence of teacher nominated as school principal. The lowest indicators in managerial competence are the utilization of ICT and monitoring and evaluation. Both indicators are found in the lowest level in most provincial respondents. However, there are some good categorical indicators in the managerial competence of principals candidates, i.e. knowledge acquisition of teacher role, student management, analyzing syllabus and lesson plan. 
The second cause is the low response of the District/City/Provincial Education Authorities to PPP policy as an effort to improve the managerial competence of teachers nominated as school principal. $42.6 \%$ of the Education Officers stated that they are not ready to follow PPP for various reasons, among which are the school principal waiting lists, cooperation with other institutions, not giving answers and disasters.

Both of these findings have implication that every teacher nominated as school principal should be equipped with managerial competencies, especially in the utilization of ICT and the implementation of monitoring and evaluation. Provincial/District/City Education Authorities must have further information about PPP from the Ministry of Eduation before appointing school principals.

To have further information about PPP, The District/City/Provincial Education Authorities should respond rapidly to the policy on PPP. PPP can be conducted through Government and Local Government budget. Every year, the Government, through LPPKS, provides quite a budget for District/City/Provincial Offices to select 50 principal candidates. District/City/Provincial Education Offices can file a budget to the local government to select and educate their principal candidates through LPPKS. So the elected principal are competent, and ready to work professionally.

Being school principal is a teacher's career path. Preparation of teacher nominated as principal is a necessity. Through PPP conducted by LPPKS, District/City/Provincial Education Authorities prepare standardized principal candidates who master five competences: personality, managerial, entrepreneurial, supervision and social, as mandated by Permendiknas Number 13 Year 20017.

This study has its own limitations. The first and the most noticeable limitation is about AKPK instrument which is a self-assessment questionaires. Every respondent has his own judgement. Indicator for ICT, for instance, respondents from Bali considered themselves incapable of utilizing ICT. Though Bali is an urban area. ICT score for Bali is the lowest. For further research, this instrument needs to be revised to avoid misunderstanding.

The second limitation is the absence of respondents from the Education Authorities to answer the second research question. The information for "how does Educational Authorities respond to the PPP?" only came from The Head and staff of Seksi Peningkatan Kompetensi of LPPKS. For further research, it should be in-depth interview with Education Authorities to get more information about their commitment in PPP as a way of improving managerial competence of teacher nominated as shool principal.

\section{REFERENCE}

[1] Sulfiati. 2013. "Kontribusi Kompetensi Manajerial Kepala Sekolah terhadap Motivasi Kerja Guru SMP Negeri di Kecamatan Padang Timur," Jurnal Administrasi Pendidikan Vol 1, Bahana Manajemen Pendidikan 228-461: hlm.9-11.

[2] Sulistyorini. 2001. Hubungan antara Keterampilan Manajerial Kepala Sekolah dan Iklim Organisasi dengan Kinerja Guru. Jurnal Ilmu Pendidikan, Vol 28, No 1:hlm.8-10.

[3] Sion, Holten. 2007. "Hubungan Keterampilan Manajerial Kepala Sekolah dan Kepuasan Kerja Guru dengan Performansi Mengajar Guru,” Jurnal Ilmu Pendidikan, Vol 14, No 2:hlm.13-14.

[4] Gurr, David. 2015. "A Model of Successful School Leadership from the International Successful School Principalship Project”. Societies, Vol 5, p.136-150.

[5] Sybouts, Ward and Frederick C. Wendel. 1994. The Training and Development of School Principals. London: Greenwood Press. p.21. 
[6] Juwita, Ratna, Siti Budiah, dan I Nyoman Rudi Kurniawan. 2015. "Pola Pendidikan dan Pelatihan yang Efektif untuk Guru dengan Tugas Tambahan Kepala Sekolah”. Prosiding Simposium Nasional Riset Pendidikan II Tahun 2015 “Guru Transformatif untuk Pendidikan yang Lebih Baik”. Jakarta. hlm.39-40.

[7] Analytical And Capacity Development Partnership 007. 2013. "Studi Dasar tentang Kompetensi Kepala Sekolah/Madrasah dan Pengawas Sekolah/Madrasah”. Program Kemitraan untuk Pengembangan Kapasitas dan Analisis Pendidikan (ACDP).hlm.67-72.

[8] Rosalina, Risa. 2013. "Persepsi Guru tentang Kompetensi Manajerial Kepala Sekolah di Sekolah Dasar Negeri Kecamatan Padang Timur, Kota Padang”. Jurnal Administrasi Pendidikan Vol 1, Bahana Manajemen Pendidikan.hlm.9-11

[9] Analytical And Capacity Development Partnership 042. 2016. "Evaluasi Program Penyiapan Kepala Sekolah". Badan Penelitian dan Pengembangan, Kementerian Pendidikan dan Kebudayaan. hlm.5052.

[10] Widodo, Erna dan Mukhtar, 2000. Konstruksi Kearah Penelitian Deskriptif. Yogyakarta: Avyrouz.hlm.87.

[11] Nazir, Moh. 2011. Metode Penelitian. Cetakan 6. Bogor: Ghalia Indonesia 5. hlm 4.

[12] Purwanto, 2007. Instrumen Penelitian Sosial dan Pendidikan. Yogyakarta: Pustaka Pelajar. hlm.107

[13] Sugiyono. 2012. Statistika Untuk Penelitian. Bandung: Penerbit Alfabeta. hlm.124.

[14] Botha, R.J. 2011. The Managerial Role of the Principal in Promoting Teacher Professionalism in Selected Eastern Cape Schools. University of South Africa Press. p.405-414.

[15] Darling, Linda and Hammond. 2010. "Preparing Principals for Changing World". Sanfransisco.John Wiley \& Sons, Inc. p.19-20.

[16] Sharp, William L. and James K. Walter. 2003.“The Principal s School Manager”. Second Edition. Oxford: The Scarecrow Press, Inc.p.9-11

[17] Lortie, Dan C.2009. "School Principal Managing in Public". The University of Chicago Press.p.3132. 